\title{
Decline of planted lodgepole pine in the southern interior of British Columbia
}

\author{
by W. Jean Mather ${ }^{1}$, Suzanne W. Simard ${ }^{2}$, Jean L. Heineman ${ }^{3}$ and Donald L. Sachs ${ }^{4}$
}

\begin{abstract}
Lodgepole pine is extensively planted across western Canada but little is known about development of these stands beyond the juvenile stage. We quantified stocking status and damage incidence in sixty-six 15- to 30-year-old lodgepole pine plantations that had previously been declared free-growing in the southern interior of British Columbia. The stands were located in six biogeoclimatic zones: Engelmann Spruce-Subalpine Fir (ESSF), Montane Spruce (MS), Interior Cedar-Hemlock (ICH), Interior Douglas-fir (IDF), Sub-Boreal Spruce (SBS), and Sub-Boreal Pine-Spruce (SBPS). Freegrowing standards were no longer met on $27 \%$ of plantations, with the worst performance ( $70 \%$ no longer free-growing) in the Interior Cedar-Hemlock forests. Natural regeneration was common but it was half the size of lodgepole pine. Biotic damage, especially hard pine stem rusts, was the dominant factor reducing free-growing densities. Stands were at greater risk of reduced stocking where summer precipitation was higher or soil moisture regimes were wetter and where stands had been broadcast-burned prior to planting or received secondary treatments of brushing or pruning. Reforestation policies that encourage widespread planting of lodgepole pine, particularly in areas where lodgepole pine has limited natural occurrence such as in the ICH zone, should be reconsidered given that health problems are extensive and are expected to increase with climate change.
\end{abstract}

Key words: Pinus contorta, lodgepole pine, free-growing, stocking, forest health, damage, disease

\section{RÉSUMÉ}

Le pin lodgepole est planté à grande échelle partout dans l'Ouest canadien, mais on sait peu de chose sur le développement de ces peuplements au-delà du stage juvénile. Nous avons quantifié la densité relative et l'incidence des dégâts de 66 plantations de pin lodgepole âgées de 15 à 30 ans qui avaient été déclarées comme étant établies et retrouvées dans la zone intérieure sud de la Colombie-Britannique. Les peuplements étaient répartis entre six zones biogéoclimatiques : épinette d'Engelmann - sapin subalpin (ESSF), épinette alpestre (MS), pruche-cèdre - intérieur (ICH), Douglas taxifolié - intérieur (IDF), épinette des forêts boréales moyennes (SBS) et épinette et pin des forêts boréales moyennes (SBSP). Les normes utilisées pour fin détablissement de la plantation nétaient plus respectées dans $27 \%$ des plantations, la pire performance ( $70 \%$ déchec) se retrouvant dans les forêts de pruche-cèdre. La régénération naturelle était fréquente mais atteignait seulement la moitié du niveau du pin lodgepole. Les dégâts biotiques, notamment les rouilles du tronc des pins durs, ont été le facteur dominant de réduction des densités relatives permettant de déclarer les plantations comme étant établies. La densité relative était plus à risque dêtre réduite dans le cas des peuplements où les précipitations au cours de lété étaient élevées ou que le régime hydrique du sol était plus humide et lorsque les peuplements avaient été soumis à un brûlage contrôlé avant plantation ou à des traitements secondaires comme le dégagement ou lélagage. Les politiques de reboisement qui encouragent la plantation à grande échelle du pin lodgepole, particulièrement dans des zones où le pin lodgepole se retrouve peu souvent de façon naturelle comme la zone pruche-cèdre - intérieur, devraient être reconsidérées étant donné que les problèmes de santé des peuplements sont importants et qu'ils devraient saccroître en fonction des changements climatiques.

Mots clés : Pinus contorta, pin lodgepole, établi, densité relative, état des forêts, dégâts, maladie

\footnotetext{
${ }^{1}$ Skyline Forestry Consultants, Ltd., 843 Arlington Court, Kamloops, British Columbia V2B 8T5.

${ }^{2}$ University of British Columbia, Forest Sciences Department, 2424 Main Mall, Vancouver, British Columbia V6T 1Z4. Corresponding author. E-mail: suzanne.simard@ubc.ca.

${ }^{3}$ J. Heineman Forestry Consulting, 2125 East 5th Ave., Vancouver, British Columbia V5N 1M5.

${ }^{4}$ Forest Research Consultant, 111 View Street, Nelson, British Columbia V1L 2V8.
} 


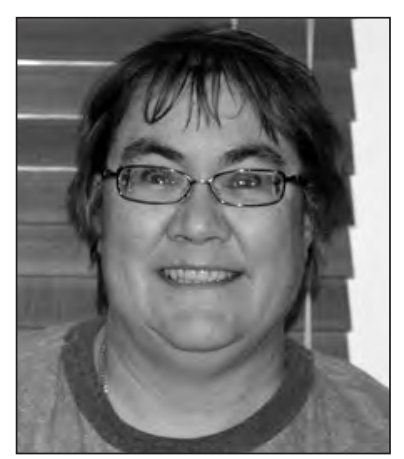

W. Jean Mather

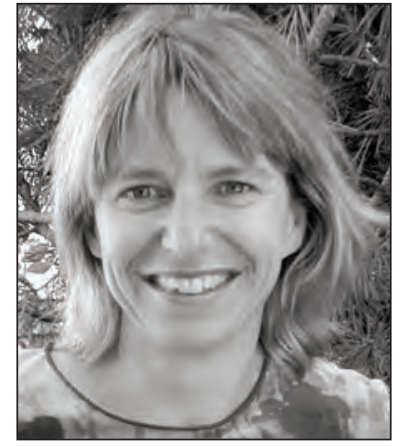

Suzanne W. Simard

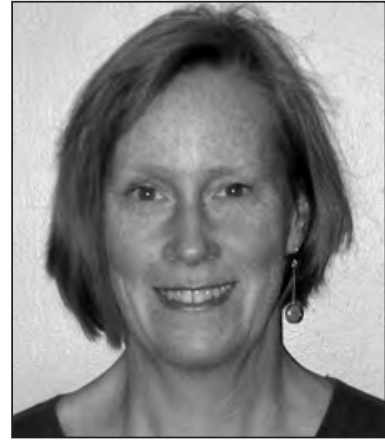

Jean L. Heineman

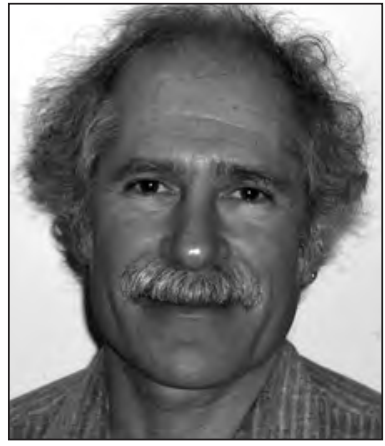

Donald L. Sachs

\section{Introduction}

Increases in tree mortality associated with climate change are occurring in forests around the world, and this is accompanied by changes in forest composition and losses in productivity, carbon sequestration and other essential ecosystem functions (Allen et al. 2010). Forest decline with climate change is especially of concern in forests that are dominated by one or a few tree species that are tightly linked to environmental limitations and disturbance. The risks of forest dieback can be further magnified by re-planting harvested sites with a single species or intensive management practices that further reduce forest structural and functional diversity (Folke et al. 2004). The extensive mature lodgepole pine (Pinus contorta Dougl. ex Loud. var. latifolia Engelm.) forests of western North America, for example, have experienced a massive die-back from an epidemic of mountain pine beetle (Dendroctonus ponderosae Hopk.) associated with the interaction of warmer winter temperatures and drier summers with the contiguous availability of suitable host tree species arising from historic fire patterns and fire suppression (Kurz et al. 2008).

Lodgepole pine is the dominant species in the dry, cold forests of western North America, commonly forming pure successional stands over vast areas of the montane and subboreal forests or occurring as a co-dominant in temperate or subalpine forests of the interior of British Columbia (Klinka et al. 2000). It has been extensively planted in British Columbia over the past four decades, representing 55\% all trees planted in the province annually (BCMFR 2002-2009). Although lodgepole pine is a desirable reforestation species due to its initial high rates of survival, rapid early growth, and tolerance of a range of site conditions (Burns and Honkala 1990, Klinka et al. 2000), there is mounting evidence that its extensive planting, including in naturally mixed forest types with historically low lodgepole pine composition, is contributing to declining overall stand health beyond the age of approximately 15 years. For example, increased decadal summer precipitation and increasing climate-related tree stresses were associated with an unprecedented outbreak of Dothistroma needle blight (Dothistroma septosporum [Dorog.] Morelet) in central British Columbia (Woods et al. 2005). Other reports suggest increasing incidence of hard pine stem rusts, stem cankers, insects, root damage and root disease in juvenile lodgepole pine stands (Simard et al. 2005, Robert and Lindgren 2006, Kurz et al. 2008).
Interactions between climate change and forest management can affect tree mortality and damage in multiple ways, from direct physiological stresses caused by wetter, warmer or drier weather on single species with poor site matching, to indirect effects of temperature and precipitation changes on insect and disease population dynamics. According to the Manion decline spiral, trees already under stress due to poor management practices (predisposing factors) can interact with climate (inciting factors) and damaging biotic agents (contributing factors) to cause tree mortality (Manion 1991).

A major contemporary challenge in predicting the effects of climate change and management practices on forest structure and function is in understanding the extent and causes of tree recruitment, damage and mortality after disturbance (Lorimer 1981, Kobe and Coates 1997). Many studies of seedling regeneration dynamics have focused on resource- or density-dependent mortality (Kobe and Coates 1997), but mortality and damage caused by biotic and abiotic disturbance agents are relatively poorly explored, particularly in relation to climatic variation and management practices. There is a vast inventory of poorly monitored plantations in western North America that provides an untapped opportunity to investigate the extent and causes of tree mortality and damage. Improving our understanding of how climate, environment and management factors interact with disturbance agents to drive forest regeneration, damage and mortality is an important component of predicting forest productivity and managing forest development in our changing climate.

The performance of forest regeneration in British Columbia is evaluated using legislated standards for stocking and health of established juvenile stands. Juvenile stands are considered effectively reforested and productive over the long term once they are declared free-growing (FG), which is based on an assessment of their stocking, competitive status, growth rates and damage (BCMF 2000, Lieffers et al. 2007). Considerable controversy exists around FG legislation, however, because of direct management costs and indirect ecological costs of meeting the standards, such as encouragement of establishment of a simple subset of fast-growing, early successional species such as lodgepole pine. Additionally, practices such as brushing, weeding or spacing are often applied to improve free-growing status of stands, but they remove native tree species that are important components of secondary succession (Perry et al. 2008) and simplify stand composition 
and structure (Simard and Vyse 2006). Moreover, studies show that meeting FG standards is poorly linked to stand performance, with FG stands commonly performing similarly or worse than unmanaged plantations (Simard et al. 2005, Lieffers et al. 2007). Once declared free-growing, stands are assumed to remain healthy and productive until maturity, but there is no systematic monitoring system to verify this. This is cause for concern because changing climatic conditions and unintended ecological consequences of the FG legislation on longer-term stand development are not well understood. Undocumented losses in free-growing stocking due to tree mortality and damage have the potential to not only undermine timber supply projections but also to seriously impact ecosystem structure and function, with large potential feedbacks to regional climate, hydrology, and carbon budgets (Chapin et al. 2008, Allen et al. 2010).

This study investigates stocking (as an inverse proxy for mortality) and damage in lodgepole pine plantations across the southern interior of British Columbia that were previously declared free-growing. Our four specific objectives were: (1) to determine whether lodgepole pine plantations previously declared free-growing are continuing to meet stocking and free-growing standards past the juvenile stage (at ages 15 to 30 years); (2) to quantify the biotic and abiotic causes of damage leading to reductions in stocking; (3) to quantify and characterize stocking of naturally regenerated species other than lodgepole pine; and (4) to identify the climatic, environmental and silviculture treatment factors that are associated with declines in free-growing status as a result of damage.

\section{Methods}

\section{Site selection}

We randomly selected 66 harvested sites in southern interior $\mathrm{BC}$ where lodgepole pine was the leading regenerating tree species from the BC Ministry of Forests RESULTS database ${ }^{5}$ (Fig. 1, Table 1). Sites were $\geq 15$ ha in size, had been planted with lodgepole pine between 1977 and 1992, and met provincial standards for free-growing prior to 2007 (BCMF 2000). Free-growing trees are defined as well-spaced trees (healthy trees of preferred or acceptable species that are at least the minimum horizontal distance from other well-spaced trees), free from damage as defined in the free-growing and advance regeneration acceptability criteria, the minimum height as specified in the Silviculture Prescription or Establishment to Free-growing Guidebook, and free from unacceptable brush competition as defined in the Establishment to Free-Growing Guidebook (Table 2). The selected sites were situated from latitude $49.0^{\circ}$ to $52.9^{\circ} \mathrm{N}$ and from longitude $115.5^{\circ}$ to $123.5^{\circ} \mathrm{W}$, at elevations ranging from $620 \mathrm{~m}$ to $1690 \mathrm{~m}$. The absolute soil moisture regime, aspect, slope, and slope positions were variable. The sites spanned six biogeoclimatic zones, including the Engelmann Spruce-Subalpine Fir (ESSF), Interior Cedar-Hemlock (ICH), Interior Douglas-fir (IDF), Montane Spruce (MS), Sub-Boreal Spruce (SBS), and Sub-Boreal Pine-Spruce (SBPS) zone (see detailed description of the zones in Meidinger and Pojar 1991). The regional climate of

\footnotetext{
${ }^{5}$ The RESULTS database (restricted access) is found at http://www. for.gov.bc.ca/his/results/access.htm
}

the study sites was continental with mild summers and moderately cold winters with most precipitation falling as snow.

\section{Field sampling}

At each site, nine $3.99-\mathrm{m}$ radius $\left(50 \mathrm{~m}^{2}\right)$ plots on average were systematically established at $100-\mathrm{m}$ intervals along a randomly located transect; this plot density was lower than operational standards due to funding constraints (total of 559 plots across all sites). Elevation, latitude and longitude were recorded at the start of each transect. Slope, aspect, slope position, and absolute soil moisture regime (i.e., based on conversion from a relative to absolute scale for southern interior sites according to Lloyd et al. [1990]) were recorded for each plot. Aspect was recorded in degrees and later converted to the continuous variables, northness (cosine [aspect $\times$ $(3.14159 / 180)])$ and eastness (sine [aspect (3.14159/180)]). Soil moisture regime was based on site characteristics (presence of indicator species in the understory vegetation, slope position, aspect and soil texture) and was converted to a continuous scale of 2 (very dry) to 6 (very moist).

Within each plot, the total, well-spaced and free-growing conifer densities were recorded based on provincial standards and site-specific silviculture prescriptions. Conifer and broadleaf (including trembling aspen [Populus tremuloides Michx.], paper birch [Betula papyrifera Marsh.], and black cottonwood [Populus balsamifera L. ssp. trichocarpa (Torr. \& A. Gray ex Hook.) Brayshaw]) densities by height class $(<2 \mathrm{~m}$, 2-4 $\mathrm{m}$, and $>4 \mathrm{~m}$ ) were also recorded. Diameter at breast height $(\mathrm{DBH})$ was recorded for all well-spaced trees. Symptomatic presence of disease, insect, animal, and abiotic damage was recorded for all lodgepole pine $\geq 50 \mathrm{~cm}$ tall according to Henigman et al. (2001). In each case where damage was recorded, the tree was assessed as to whether it met health standards defined by British Columbia provincial free-growing guidelines (BCMF 2000). Mountain pine beetle damage is not specifically mentioned in the standards because it does not affect juvenile pine under non-epidemic conditions; however, we considered stems to be not free-growing if we found any evidence of this insect.

\section{Compilation of climate and silviculture treatment data}

Individual site latitude and longitude values were used to generate climate data from the web-based tool, Climate BC (Wang et al. 2006). Selected climate variables, means generally based on measured temperature and precipitation data for the period 1971 to 2000 (see definitions of variables in Tables 1 and 6), were initially used to predict whether stands met well-spaced and free-growing standards using logistic regression. Two derived variables (growing season degreedays and chilling period degree-days) were also used in the runs because of their relevance to forest management. Data on extreme climatic events are not available in Climate BC and thus were not assessed in this study. Information regarding silviculture treatments, including broadcast burning, mechanical site preparation, brushing, juvenile spacing, and pruning, was obtained for individual sites from the RESULTS database and site information recorded in the field surveys were also used in the logistic regression predictions. There was no evidence of a correlation between silviculture treatments that were applied and measured site quality factors. The type and date of the treatments is listed in the RESULTS database. 


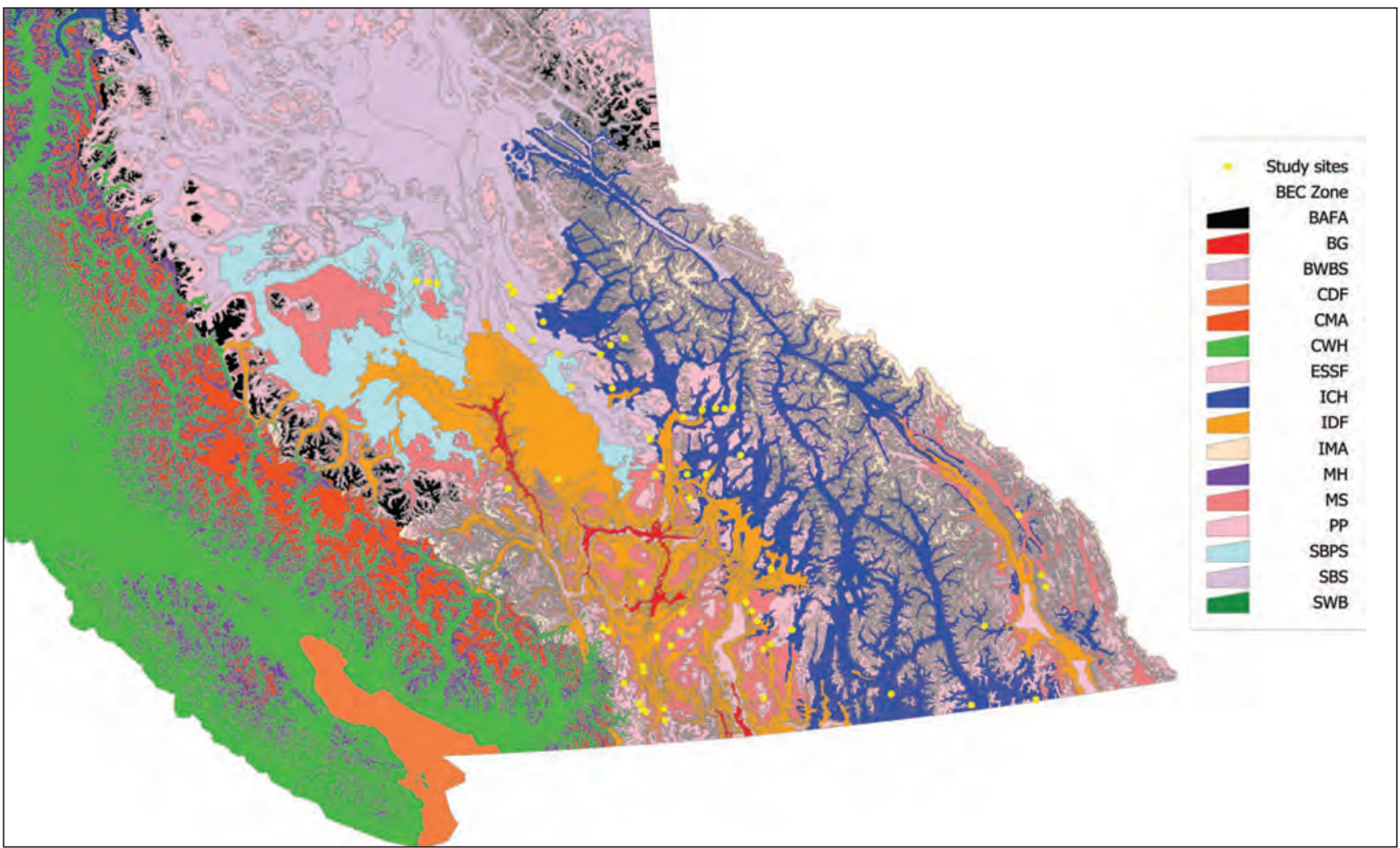

Fig. 1. Location of the 66 sites (filled yellow circles) sampled in southern interior British Columbia in 2007 and 2008 . Biogeoclimatic Ecosystem Classification (BEC) zone abbreviations are: BAFA (Boreal Altai Fescue Alpine), BG (Bunchgrass), BWBS (Boreal White and Black Spruce), CDF (Coastal Douglas-fir), CMA (Coastal Mountain-heather Alpine), CWH (Coastal Western Hemlock), ESSF (Engelmann Spruce-Subalpine Fir), ICH (Interior Cedar-Hemlock), IDF (Interior Douglas-fir), IMA (Interior Mountain-heather Alpine), MH (Mountain Hemlock), MS (Montane Spruce), PP (Ponderosa Pine), SBPS (Sub-Boreal Pine-Spruce), SBS (Sub-Boreal Spruce), SWB (Spruce-Willow-Birch) (Meidinger and Pojar 1991, MacKenzie and Meidinger 2006).

\section{Data analysis}

Data were checked for outliers and normality, and summary statistics for density and disease measures were then compiled by biogeoclimatic zone. Logistic regression analysis was used to determine whether well-spaced or free-growing success, or rejection of free-growing status, was associated with climatic, geographic location, site, stand, or treatment factors. The general form of the model was:

$$
\text { [1] } \mathrm{p}(\mathrm{Y})=1 /\left(1+\exp \left[\beta_{0}+\beta_{1} \mathrm{x}_{1}+\beta_{2} \mathrm{x}_{2}+\ldots \ldots+\beta_{\mathrm{k}} \mathrm{x}_{\mathrm{k}}\right]\right)
$$

where $\mathrm{p}(\mathrm{Y})$ is the probability of a plot meeting the provincial standard, $\beta_{0}$ is the intercept, $\beta_{1} \ldots \beta_{\mathrm{k}}$ are estimated coefficients, and $\mathrm{x}_{1} \ldots \mathrm{x}_{\mathrm{k}}$ are independent location, site, stand, climatic, or treatment variables.

Logistic regression analyses were performed using SAS PROC LOGISTIC (SAS Institute Inc. 2002-2003). A total of 559 plots and 6094 trees were used in the analysis. The events/trials syntax of PROC LOGISTIC was used, where events were equal to the number of trees on a plot declared well-spaced or free-growing and trials were equal to the total number of trees on the plot. For predicting the probability that a tree was rejected as free-growing, events were equal to the number of all trees rejected in the study and trials were equal to the total number of trees in the study. Predictive factors were continuous (e.g., elevation, northness, eastness, latitude, longitude, soil moisture, pine density and climatic vari- ables), categorical (e.g., slope position), or binary (silviculture treatments). Silviculture treatments (i.e., burning, mechanical preparation, brushing, juvenile spacing, or pruning) were coded as "yes" or "no" for each plot. For each stocking variable, a stepwise regression model was fitted with predictive factors allowed to enter or leave the model automatically using probability Wald chi-square $\left(\chi^{2}\right) \leq 0.05$ as the default criteria for inclusion. The order in which individual factors were accepted into the model reflects their relative probability $\chi^{2}$ value, and therefore their relative importance in the model. For each factor included in the final model, odds of a tree being free-growing, well-spaced or rejected (i.e., the probability of an event divided by the probability of nonevent) were calculated, and an odds-ratio (the multiplicative factor by which risk changed when the independent variable increased by one unit) was determined. Due to the logarithmic nature of odds-ratios, a change of " $x$ " units of the predictive factor corresponded with a change in stocking status that was the value of the odds ratio raised to the power of " $x$ ". Odds-ratios above 1 indicated increased probability and those below 1 indicated decreased probability. To assess the model performance in discriminating between free-growing, well-spaced or rejected lodgepole pine and all lodgepole pine, we used the Area Under the Curve (AUC) statistic. The degree to which AUC exceeds 0.5 is a measure of the degree to which the model improves predictive ability in comparison with random chance. 
Table 1. Summary of elevation, climatic, and tree species characteristics of the study sites by biogeoclimatic zone

\begin{tabular}{|c|c|c|c|c|c|c|}
\hline \multirow[b]{2}{*}{ Variable description } & \multicolumn{6}{|c|}{ Biogeoclimatic zone } \\
\hline & ESSF & ICH & IDF & MS & SBS & SBPS \\
\hline Number of study sites & 10 & 17 & 5 & 21 & 8 & 5 \\
\hline Elevation (m) & $1220-1690$ & $620-1275$ & $1000-1375$ & $1105-1630$ & $910-1405$ & $965-1260$ \\
\hline Climate description $^{\mathrm{a}}$ & $\begin{array}{l}\text { Cool short } \\
\text { growing } \\
\text { seasons; } \\
\text { long cold } \\
\text { winters }\end{array}$ & $\begin{array}{l}\text { Warm dry } \\
\text { summers; } \\
\text { cool, wet } \\
\text { winters }\end{array}$ & $\begin{array}{l}\text { Warm, dry } \\
\text { summers; } \\
\text { long growing } \\
\text { season; } \\
\text { cool winters }\end{array}$ & $\begin{array}{l}\text { Moderately } \\
\text { short, warm } \\
\text { summers; } \\
\text { cold winters }\end{array}$ & $\begin{array}{l}\text { Relatively } \\
\text { warm, moist, } \\
\text { short } \\
\text { summers; } \\
\text { severe, snowy } \\
\text { winters }\end{array}$ & $\begin{array}{l}\text { Cool, dry } \\
\text { summers; } \\
\text { cold dry } \\
\text { winters }\end{array}$ \\
\hline Mean warmest monthly temperature $(\mathrm{MWMT})\left({ }^{\circ} \mathrm{C}\right)^{\mathrm{b}}$ & 13.0 & 14.9 & 14.1 & 13.9 & 14.0 & 13.1 \\
\hline Mean coldest monthly temperature $\left(\operatorname{MCMT}\left({ }^{\circ} \mathrm{C}\right)^{\mathrm{b}}\right.$ & -8.3 & -7.8 & -6.7 & -7.1 & -8.2 & -9.2 \\
\hline Mean annual precipitation $(\mathrm{MAP})(\mathrm{mm})^{\mathrm{b}}$ & 941 & 798 & 761 & 722 & 552 & 588 \\
\hline Mean summer precipitation (MSP) $(\mathrm{mm})^{\mathrm{b}}$ & 354 & 326 & 276 & 264 & 289 & 304 \\
\hline Total number of frost-free days (TNFFD) (days) ${ }^{\mathrm{b}}$ & 143 & 162 & 153 & 156 & 151 & 138 \\
\hline Number of continuous frost-free days (TNCFFD) (days) ${ }^{b}$ & )$^{\mathrm{b}} \quad 37$ & 89 & 77 & 79 & 78 & 62 \\
\hline Average soil moisture index $(\mathrm{ASM})^{\mathrm{c}}$ & 4.5 & 4.1 & 2.4 & 2.9 & 4.4 & 3.7 \\
\hline Climax tree species ${ }^{\mathrm{a}}$ & $\mathrm{Se}^{\mathrm{d}}, \mathrm{Bl}$ & $\begin{array}{c}\mathrm{Cw}, \mathrm{Hw} \\
(\mathrm{Sxw}, \mathrm{Bl}, \mathrm{Act})\end{array}$ & $\begin{array}{c}\text { Fd, Pl, } \\
\text { Sxw (Cw) }\end{array}$ & Sxw, Bl, Fd & Sxw, Bl, Pl & $\mathrm{Pl}, \mathrm{Sw}$ \\
\hline Common seral tree species ${ }^{\mathrm{a}}$ & $\mathrm{Pl}$ & $\begin{array}{c}\text { Fd, Pl, Lw, } \\
\text { Pw, Sxw, Bl, } \\
\text { Ep, At, Act }\end{array}$ & $\begin{array}{l}\mathrm{Pl}, \mathrm{At}, \mathrm{Ep} \\
\quad(\mathrm{Lw})\end{array}$ & $\begin{array}{c}\mathrm{Pl}, \mathrm{Sxw}, \mathrm{Bl}, \\
\mathrm{Fd}, \mathrm{At} \\
(\mathrm{Lw}, \mathrm{Cw}, \mathrm{Act})\end{array}$ & $\begin{array}{l}\mathrm{Pl}, \mathrm{At} \\
\mathrm{Ep}, \mathrm{Fd}\end{array}$ & $\begin{array}{c}\mathrm{Pl}, \mathrm{At} \\
(\mathrm{Fd}, \mathrm{Bl}, \mathrm{Act})\end{array}$ \\
\hline
\end{tabular}

a'General zone characteristics as described by Meidinger and Pojar (1991).

betermined from Climate BC for the period of 1971-2000 (Wang et al. 2006) based on latitude and longitude recorded at individual study sites.

'From Heineman et al. 2010. Based on conversion of categorical values (see Methods).

${ }^{\mathrm{d}}$ Tree species codes (in alphabetical order): Act (black cottonwood, Populus balsamifera ssp. trichocarpa), At (trembling aspen, Populus tremuloides), Bl (subalpine fir, Abies lasiocarpa), Cw (western redcedar, Thuja plicata), Ep (paper birch, Betula papyrifera), Fd (Douglas-fir, Pseudotsuga menziesii), Hw (western hemlock, Tsuga heterophylla), Lw (western larch, Larix occidentalis), Pl (lodgepole pine, Pinus contorta), Pw (western white pine, Pinus contorta), Se (Engelmann spruce, Picea engelmannii), Sw (white spruce, Picea glauca), Sxw (hybrid spruce, Picea engelmannii $\times$ glauca)

\section{Table 2. Glossary of terms}

\begin{tabular}{ll}
\hline Term & Meaning \\
\hline Silviculture prescription (SP) & \\
Target stocking standard (TSS) & $\begin{array}{l}\text { A silviculture prescription outlines the required management objectives, standards, and timelines } \\
\text { that the owner of the opening must achieve, including reaching a free-growing stand. }\end{array}$ \\
& $\begin{array}{l}\text { Target stocking is the number of well-spaced preferred and acceptable trees per hectare that will, } \\
\text { under normal circumstances, produce an optimum free-growing crop. On circum-mesic sites, TSS } \\
\text { has averaged } 1200 \text { stems ha }^{-1} \text {, although planting density is often higher (up to } 1600 \text { stems ha } \\
\text { TSS is } 50 \% \text { to } 70 \% \text { higher than the MSS. Significant volume reductions are projected if stands are } \\
\text { managed to minimum rather than target stocking standards. }\end{array}$
\end{tabular}

Minimum stocking standard (MSS) ${ }^{\mathrm{b}} \quad$ Minimum stocking standard is the lowest number of acceptable well-spaced stems per hectare required to consider an area satisfactorily stocked at the free-growing stage.

Well-spaced (WS) ${ }^{\mathrm{b}}$

Well-spaced trees are healthy trees of preferred or acceptable species that are at least the minimum horizontal inter-tree distance from other well-spaced trees. The inter-tree distance is specified in the silviculture prescription and is usually $2 \mathrm{~m}$.

Free-growing $(\mathrm{FG})^{\mathrm{b}}$

A free-growing tree must be well-spaced and a preferred or acceptable species as outlined in the SP, free from damage as defined in the free-growing damage criteria, the required minimum height specified in the SP or in the Establishment to Free Growing Guidebook, and free from unacceptable brush and broadleaf tree competition as described in the Establishment to Free Growing Guidebook.

Preferred and acceptable species ${ }^{\mathrm{b}} \quad$ Preferred and acceptable species are those species that are ecologically suited to the site. Preferred species are those that best meet the management objectives for a site and will produce the greatest volume of high quality sawlogs over the rotation. Acceptable species may occur as a component of mixed stands but are not considered to be the target species for a site.

Lethal damage

Lethal damage refers to damage that prevents a tree from being well-spaced and free-growing. 
Table 3. Total, well-spaced, and free-growing stocking and proportion of sites meeting minimum stocking standards by biogeoclimatic (BEC) zone

\begin{tabular}{|c|c|c|c|c|c|c|c|c|}
\hline \multirow[b]{2}{*}{ BEC zone } & \multicolumn{4}{|c|}{ Conifer stocking } & \multicolumn{2}{|c|}{$\begin{array}{l}\text { Proportion of sites } \\
\text { meeting minimum } \\
\text { stocking standards }\end{array}$} & \multicolumn{2}{|c|}{$\begin{array}{l}\text { Proportion of sites } \\
\text { with }>100 \text { stems/ha } \\
\text { above minimum } \\
\text { stocking standards }\end{array}$} \\
\hline & $\begin{array}{c}\text { Total conifers } \\
\text { (stems/ha) }\end{array}$ & $\begin{array}{l}\text { Lodgepole pine } \\
\text { (stems/ha) }\end{array}$ & $\begin{array}{l}\text { Well-spaced } \\
\text { (stems/ha) }\end{array}$ & $\begin{array}{c}\text { Free- } \\
\text { growing } \\
\text { (stems/ha) }\end{array}$ & $\begin{array}{l}\text { Well- } \\
\text { spaced } \\
(\%)\end{array}$ & $\begin{array}{l}\text { Free- } \\
\text { growing } \\
(\%)\end{array}$ & $\begin{array}{l}\text { Well- } \\
\text { spaced } \\
(\%)\end{array}$ & $\begin{array}{l}\text { Free- } \\
\text { growing } \\
(\%)\end{array}$ \\
\hline ESSF & $2807 \pm 226$ & $1500 \pm 168$ & 926 & 862 & 90.0 & 90.0 & 90.0 & 70.0 \\
\hline $\mathrm{ICH}$ & $3359 \pm 372$ & $1611 \pm 131$ & 812 & 702 & 58.8 & 29.4 & 41.2 & 29.4 \\
\hline IDF & $2462 \pm 233$ & $2120 \pm 237$ & 865 & 812 & 100.0 & 100.0 & 60.0 & 60.0 \\
\hline MS & $3107 \pm 179$ & $2350 \pm 149$ & 927 & 912 & 90.5 & 85.7 & 81.0 & 61.9 \\
\hline SBPS & $4043 \pm 343$ & $2759 \pm 328$ & 952 & 851 & 100.0 & 80.0 & 80.0 & 20.0 \\
\hline SBS & $4320 \pm 600$ & $3769 \pm 541$ & 968 & 850 & 87.5 & 75.0 & 75.0 & 75.0 \\
\hline
\end{tabular}

\section{Results \\ Total stocking}

Mean total stocking ranged from 2462 to 4320 stems/ha across all biogeoclimatic zones, with only $6 \%$ of stands falling below 1200 stems/ha (Table 3 ). Most sites were not excessively dense; only one site had $>6000$ stems/ha and over $75 \%$ had less than 4000 stems/ha (data not shown). Total density of all species combined was highest in the SBS and SBPS zones, intermediate in the MS and $\mathrm{ICH}$, and lowest in the ESSF and IDF. Density of lodgepole pine was the highest in the SBS zone (3769 stems/ha), and lowest in the ESSF and ICH (1500-1611 stems/ha).

\section{Free-growing and well-spaced stocking}

At the time free-growing was declared, five to 13 years before our surveys, all 66 sites met minimum free-growing and wellspaced requirements, 5\% met target free-growing densities and $18 \%$ met target well-spaced densities. In 2007, our surveys revealed that $27 \%$ of all lodgepole pine stands assessed were no longer free-growing at age 15 to 30 . Only $5 \%$ of sites had $>1100$ free-growing stems/ha, indicating that almost all sites fell substantially short of the targets (1200 stems/ha on most sites) set by the BC Ministry of Forests (2000) (data not shown). Fifteen percent of sites were severely under-stocked ( $<550$ free-growing stems/ha), $48 \%$ of stands fell within 100 stems per hectare of the minimum stocking standard (700 stems/ha on most sites), and $85 \%$ of stands were at least 200 stems per hectare below the target density. The Forest Practices Board (2003) considered stands with stocking within 100 stems/ha of the minimum stocking density to be at high risk of not achieving their full productivity potential.

Performance varied with biogeoclimatic zone (Table 3) and was clearly the worst in the ICH, where $70 \%$ of the plantations surveyed were no longer free-growing and $40 \%$ no longer met the well-spaced requirement. Within the ICH zone, performance was worse in the wettest subzone (ICHwk [wet, cool]), where none of the plantations were still freegrowing at the time of our survey, than the drier subzones (ICHdk [dry, cool], ICHmk [moist, cool], ICHmw [moist, warm]). Low densities of free-growing and well-spaced stems were associated with lower total stand density; only $42 \%$ of our sites with $<2000$ total stems/ha met minimum free-grow- ing requirements, whereas $85 \%$ of the sites with $>2000$ total stems/ha were free-growing (data not shown).

\section{Species other than lodgepole pine}

Natural regeneration of species other than lodgepole pine was common in most plantations $(\geq 1000$ stems/ha on $73 \%$ of sites). The density of free-growing trees other than lodgepole pine varied from 72 to 233 stems/ha across all biogeoclimatic zones, representing on average $25 \%$ of the free-growing stocking for the ICH, ESSF, and SBS zones, and $9 \%$ of the freegrowing stocking for the IDF, MS and SBPS zones (Table 3, Fig. 2). When considering total stocking, we found that species other than lodgepole pine accounted for more than half of the regeneration in the ICH and ESSF zones, whereas other biogeoclimatic zones had both more lodgepole pine and lower densities of other species. Species composition varied with biogeoclimatic zone, but overall, interior spruce occurred at the highest densities and subalpine fir was the most common (absent only from the SBPS) (Fig. 2). The ICH zone had the greatest diversity of non-lodgepole pine species (seven conifer species) while the SBPS had the least (only interior spruce). Lodgepole pine was generally taller and larger in diameter than the other species. Most lodgepole pine trees were in the $>4 \mathrm{~m}$ height class, whereas most other tree species were $<2 \mathrm{~m}$ tall, except those that were chosen as wellspaced and free-growing stems, which were mostly $>2 \mathrm{~m}$ tall (Fig. 3). The average diameter of well-spaced lodgepole pine was $9.5 \mathrm{~cm}$ compared to $4.9 \mathrm{~cm}$ for other species.

\section{Factors causing free-growing reductions}

Lodgepole pine suffered damage on all sites surveyed (Table 4) and was the principal reason why many plantations failed or marginally met free-growing and well-spaced stocking standards. By contrast, meeting minimum height and competitive status requirements were not important factors reducing densities of free-growing lodgepole pine. Lodgepole pine was most damaged in the ICH, SBS and SBPS zones (64\%-68\% of total lodgepole pine damaged), followed by the ESSF (57\% damaged), MS (45\% damaged), and IDF (34\% damaged) (Table 4). Overall, more than $90 \%$ of the damage was serious enough for the trees to be rejected as free-growing (i.e., lethal damage, Table 4). 


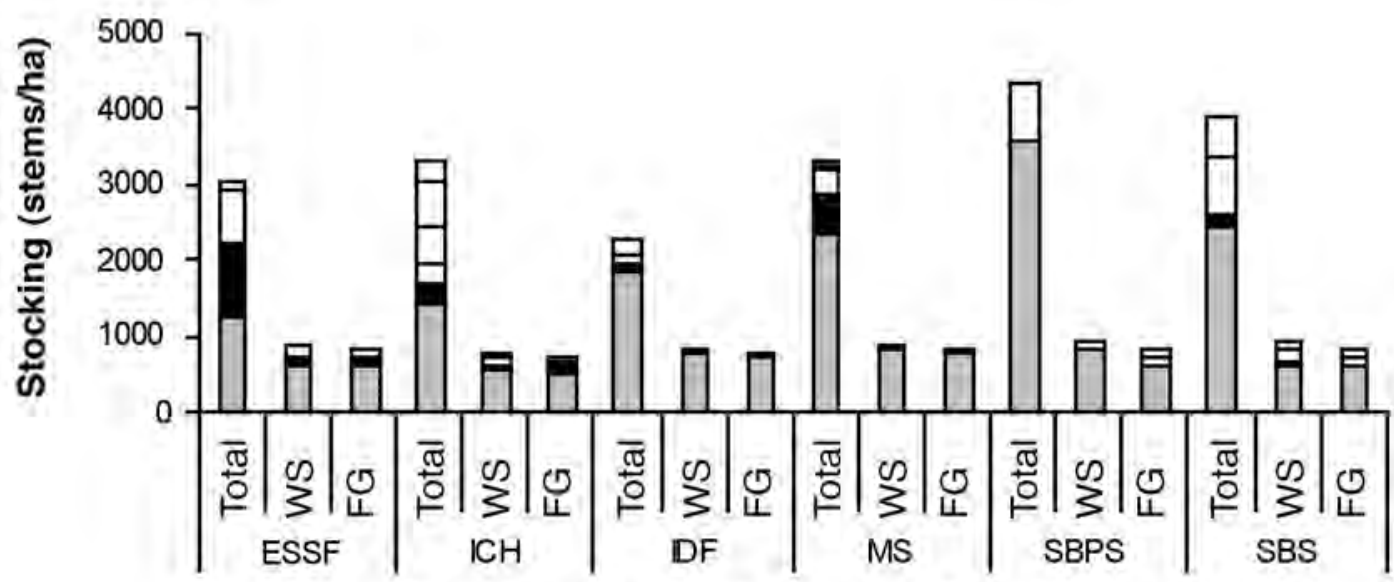

Stocking category by biogeoclimatic zone

$\square \mathrm{PI} \equiv \mathrm{BI} \square \mathrm{Se} / \mathrm{Sx} \square \mathrm{Fd} \boxminus \mathrm{CW} \square \mathrm{PW}_{\mathrm{r}} \mathrm{LW}_{1} \mathrm{HW}$

Fig. 2. Total, well-spaced (WS) and free-growing (FG) stocking by species in each biogeoclimatic zone.

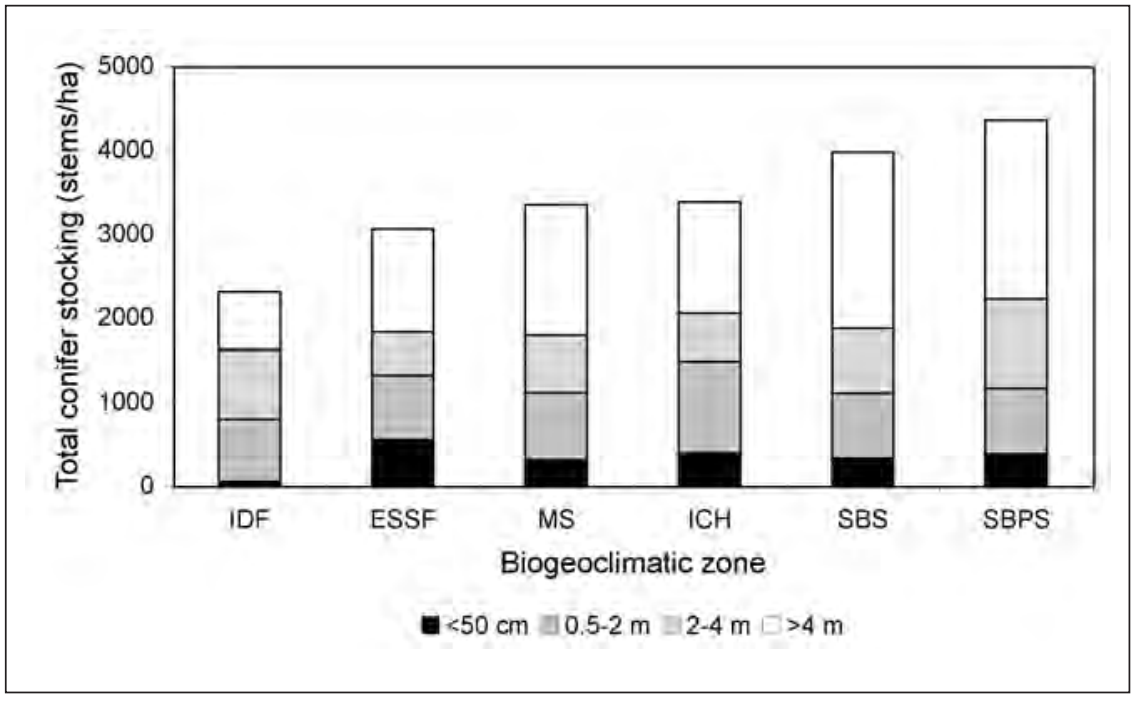

Fig. 3. Total conifer stocking by height class in each biogeoclimatic zone. than lodgepole pine ranged from $12 \%$ of secondary trees in the IDF zone to $26 \%$ in the SBS zone. The principal causes of damage were snow and ice in the ESSF zone (4.3\% of trees), drought in the IDF zone (5.5\%), foliar diseases in the ICH zone (4.3\%), and insects in the MS, SBPS and SBS zones $(10.5 \%$ to13.7\%). Logistic regression
Logistic regression revealed some sig-
nificant associations between geo-
graphic, site, stand, climatic, or treat-
ment factors and whether or not plots
were well-spaced or free-growing, or
whether individual trees were rejected
as free-growing (Table 6). Model abil-
ity to discriminate between acceptable
and unacceptable stems was moder-
ately good (AUC of 0.680 to 0.703 ) (Table 6). Odds-ratios revealed differing trends in stocking status associated with different factor types (Table 7). Site factors tended to have small units of change and low odds-ratios with relatively narrow confidence limits, while silviculture treatment variables, which were recorded as "presence" or "absence", produced both high and low odds-ratios with wider confidence limits. Spacing resulted in a higher likelihood that plots met well-spaced requirements and a lower likelihood that trees were damaged. Brushing and broadcast burning, on the other hand, reduced the likelihood that plots remained free-growing. Pruning also had a negative effect by increasing the likelihood that trees were damaged and reducing the likelihood that plots were well-spaced. Trees were more likely to be rejected as free-growing if they were older or in dense stands, but less likely to be rejected if they were north-facing or in a lower slope position. Trees were also more likely to be rejected as free-growing as latitude, soil moisture regime, tree age, stand density, and continentality 
Table 4. Proportion of sites and percentage of lodgepole pine damaged and rejected as free-growing by damage category and biogeoclimatic (BEC) zone

\begin{tabular}{|c|c|c|c|c|c|c|c|c|c|c|}
\hline $\begin{array}{l}\text { BEC } \\
\text { zone }\end{array}$ & Proportion (\%) & $\begin{array}{c}\text { All } \\
\text { agents }\end{array}$ & $\begin{array}{c}\text { All } \\
\text { diseases }\end{array}$ & $\begin{array}{c}\text { Stem } \\
\text { diseases }^{\mathrm{a}}\end{array}$ & $\begin{array}{c}\text { Foliar } \\
\text { diseases }^{b}\end{array}$ & $\begin{array}{c}\text { Root } \\
\text { diseases }^{\mathrm{c}}\end{array}$ & $\begin{array}{c}\text { Dwarf } \\
\text { mistletoe }\end{array}$ & $\underset{\text { Insects }}{\text { All }}$ & $\underset{\text { animals }^{\mathrm{e}}}{\text { All }}$ & $\begin{array}{c}\text { All } \\
\text { abiotic }^{f}\end{array}$ \\
\hline \multirow[t]{3}{*}{ ESSF } & Sites with agent on pineg & 100 & 100 & 100 & 30 & 0 & 0 & 20 & 40 & 60 \\
\hline & Damaged pine & 56.9 & 23.2 & 13.1 & 9.7 & 0.4 & 0 & 3.2 & 4.5 & 20.9 \\
\hline & Lethally damaged pine & 45.5 & 19.5 & 11.6 & 7.4 & 0.4 & 0 & 2.7 & 4.4 & 15.5 \\
\hline \multirow[t]{3}{*}{$\mathrm{ICH}$} & Sites with agent on pine & 100 & 100 & 100 & 41 & 29 & 0 & 41 & 53 & 35 \\
\hline & Damaged pine & 64.1 & 41.0 & 30.5 & 9.8 & 0.7 & 0 & 13.4 & 5.7 & 5.6 \\
\hline & Lethally damaged pine & 59.6 & 32.8 & 26.5 & 5.7 & 0.7 & 0 & 11.1 & 4.4 & 4.6 \\
\hline \multirow[t]{3}{*}{ IDF } & Sites with agent on pine & 100 & 100 & 100 & 0 & 0 & 0 & 40 & 20 & 80 \\
\hline & Damaged pine & 33.8 & 16.7 & 7.1 & 9.6 & 0 & 0 & 7.5 & 5.4 & 1.6 \\
\hline & Lethally damaged pine & 31.1 & 15.0 & 7.0 & 8.0 & 0 & 0 & 7.3 & 5.1 & 0.5 \\
\hline \multirow[t]{3}{*}{ MS } & Sites with agent on pine & 100 & 100 & 100 & 19 & 0 & 19 & 48 & 33 & 29 \\
\hline & Damaged pine & 44.7 & 32.0 & 17.0 & 12.4 & 0.7 & 1.9 & 6.4 & 5.9 & 1.6 \\
\hline & Lethally damaged pine & 42.0 & 27.9 & 15.3 & 10.0 & 0.7 & 1.9 & 5.3 & 5.2 & 1.1 \\
\hline \multirow[t]{3}{*}{ SBPS } & Sites with agent on pine & 100 & 100 & 100 & 20 & 0 & 0 & 60 & 40 & 0 \\
\hline & Damaged pine & 64.0 & 41.8 & 38.2 & 3.4 & 0.1 & 0.1 & 10.4 & 2.3 & 1.3 \\
\hline & Lethally damaged pine & 60.2 & 36.8 & 34.7 & 2.2 & 0.1 & 0.1 & 7.5 & 2.0 & 1.0 \\
\hline \multirow[t]{3}{*}{ SBS } & Sites with agent on pine & 100 & 100 & 100 & 38 & 13 & 0 & 88 & 75 & 25 \\
\hline & Damaged pine & 68.1 & 50.2 & 42.5 & 6.6 & 1.0 & 0.1 & 17.0 & 5.2 & 0.5 \\
\hline & Lethally damaged pine & 65.4 & 41.2 & 35.3 & 4.6 & 1.0 & 0.1 & 13.6 & 4.4 & 0.3 \\
\hline \multirow[t]{3}{*}{ All } & Sites with agent on pine & 100 & 100 & 100 & 27 & 9 & 6 & 33 & 44 & 36 \\
\hline & Damaged pine & 55 & 34.8 & 23.8 & 9 & .3 & 6 & 9.4 & 5.3 & 5.3 \\
\hline & Lethally damaged pine & 50.5 & 29.2 & 20.9 & 5 & .3 & 6 & 7.7 & 4.5 & 4 \\
\hline
\end{tabular}

aStem diseases include: Western gall rust (Endocronartium harknessii), Stalactiform blister rust (Cronartium coleosporioides), Comandra rust (Cronartium comandrae), Atropellis canker (Atropellis piniphila)

${ }^{\mathrm{b}}$ Foliar diseases include: Pine needle cast (Lophodermella concolor), Dothistroma needle blight (Dothistroma septosporum)

'Root diseases include: Armillaria root disease (Armillaria ostoyae), Tomentosus root rot (Inonotus tomentosus)

${ }^{\mathrm{d}}$ Insects include: Sequoia pitch moth (Synanthedon sequoiae), Mountain pine beetle (Dendroctonus ponderosae), Warren's root collar weevil (Hylobius warreni), Lodgepole pine terminal weevil (Pissodes terminalis)

eAnimals include: Bear (Ursus americanus), Deer/moose (Odocoileus spp., Alces alces), Red squirrel (Tamiasciurus hudsonicus)

${ }^{\mathrm{f}}$ Abiotic agents include: Snow and ice

gSites with agent on pine refers to the percentage of field-assessed stands where the damaging agent occurred.

increased. Plots were less likely to meet well-spaced requirements as soil moisture regime and mean summer precipitation increased, but were more likely to remain free-growing where winters were warmer.

\section{Discussion}

\section{Trends in total stand density}

Total density exceeded 1200 total trees/ha in $94 \%$ of our stands, providing clear evidence that lodgepole pine plantations are not lacking in trees in southern interior British Columbia. Contrary to management expectations, however, a large portion of the stocking was comprised of naturally regenerated species, not planted lodgepole pine, and many of the native trees occurred in slowly growing clumps rather than in an even (well-spaced) distribution. Over half $(55 \%)$ of all lodgepole pine trees were damaged, and most $(90 \%)$ of this damage was serious enough to prevent the trees from being declared free-growing. Many of these damaged trees are expected either to die or suffer such severe deformity that they will not contribute to commercial timber yield. Because of the widespread damage of lodgepole pine trees, as well as earlier losses to mortality that we were unable to quantify, $27 \%$ of all the 15 - to 30 -year-old plantations we surveyed, and
$70 \%$ of those in the ICH zone, no longer met minimum stocking standards and thus will fail to reach full potential productivity as defined by the free-growing guidelines. The ICH is the most productive forested zone in southern interior British Columbia (Meidinger and Pojar 1991). Assuming the freegrowing guidelines are a good benchmark for predicting future stand conditions, the widespread substandard performance we measured in ICH plantations and elsewhere is expected to reduce future timber supply for the province.

The naturally regenerating trees we observed were generally healthier than lodgepole pine. As a result, natural regeneration is expected to contribute to stand productivity, especially in the ICH and ESSF zones where it was most abundant. The contribution of natural regeneration to free-growing stocking was limited, however, because the trees often failed to meet minimum height requirements and because they were dispersed in clumps. Because the naturally regenerating species were usually less than half the height of lodgepole pine ( $2 \mathrm{~m}$ vs. $4 \mathrm{~m}$ tall), the surveyed stands are also expected to produce less timber volume at a designated rotation age than if lodgepole pine had grown to maturity as predicted. A $2-\mathrm{m}$ height difference in juvenile stands may underestimate volume losses, however, because tree species differ in height 


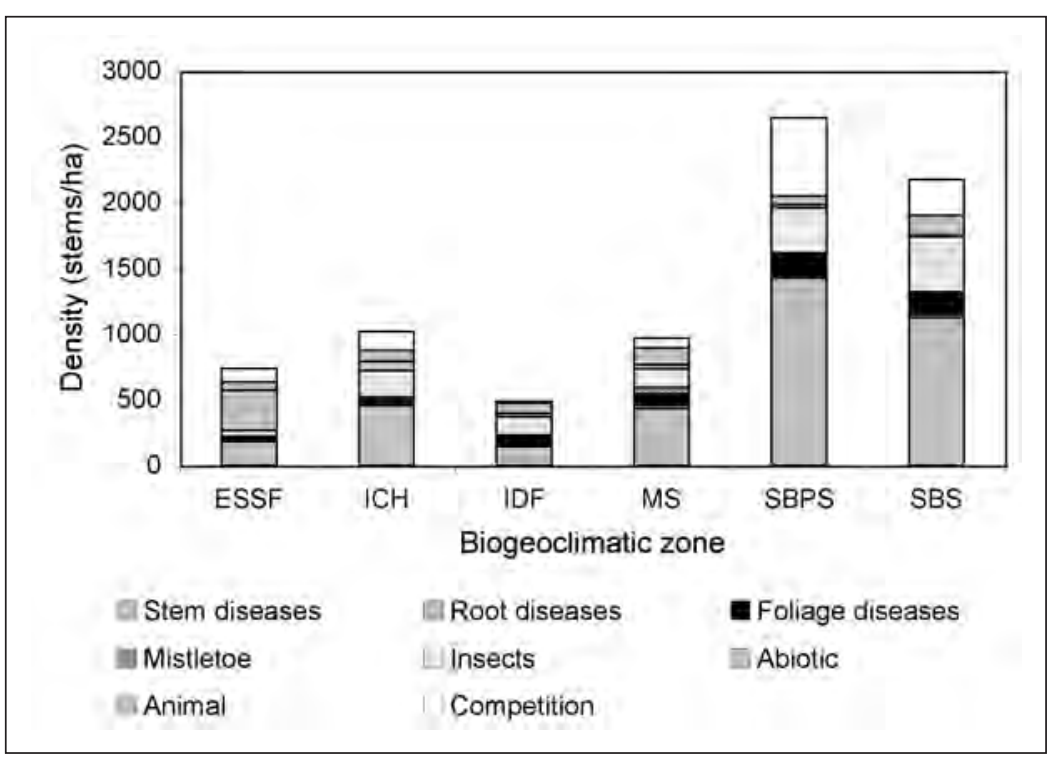

Fig. 4. Total density of trees damaged by agent group in each biogeoclimatic zone. See Table 4 for individual damaging agents in each agent group.

growth patterns, with the maximum height of most native species in our study less than that of lodgepole pine within a 100-year rotation (Claveau et al. 2002). Of greater importance, however, is the impact of damage on stocking losses, which has the potential to substantially reduce yield at rotation (Mitchell 1975). The reductions caused by stocking loss due to damage will greatly overshadow density declines that naturally occur with stand age. Using the Table Interpolation Program for Stand Yields (TIPSY v4.1; Mitchell et al. 1992), we estimated that density will decline naturally by $3 \%$ to $4 \%$ due to self-thinning over 10 years after free-growing declaration across our study sites. This is an order of magnitude lower than the $30 \%$ to $65 \%$ lethal damage rates that we observed over the same time period in our survey. Losses in yield due to pine mortality may be offset because species mixtures, which likely will become more prevalent as pine declines, can be higher than in monocultures because of functional diversity, niche complementarity or facilitation (Tilman et al. 1997, Cardinale et al. 2006, Kelty 2006) and greater resilience to insect or disease pests (Scherer-Lorenzen et al. 2005, Schaberg et al. 2008). Regardless, naturally regenerating species are likely to play a vitally important role in ecosystem function because they will fill the gaps if lodgepole pine continues to decline in health. Advance regeneration of secondary species, particularly of subalpine fir, is also sufficiently abundant in lodgepole pine stands killed by mountain pine beetle to contribute to future timber supply in interior British Columbia (Vyse et al. 2009).

\section{Free-growing trends}

Five to13 years after lodgepole pine plantations were declared free-growing, free-growing performance on many sites had declined to substantially below the targets set by the BC Ministry of Forests (2000). Fifteen percent of our sites were severely under-stocked (<550 free-growing stems/ha), $48 \%$ of stands fell within 100 stems/ha of the minimum stocking standard, and $85 \%$ of stands were at least 200 stems/ha below the target density. Sustaining free-growing status was problematic in all biogeoclimatic zones, but especially so in the ICH zone. The Forest Practices Board (2003) conducted a provincial scale reconnaissance of blocks recently after they had been declared freegrowing. Both the field work and the examination of reported compliance indicate that at the time of the free-growing declaration, and shortly thereafter, there was no cause for concern about the free-growing status. They considered stands with a free-growing density within 100 stems/ha of the target stocking as "low risk" of not achieving their full productive potential, and those with a freegrowing density within 100 stems per hectare of the minimum stocking as a "very high risk". We found that $48 \%$ of our surveyed stands fell into the "very high risk" category and only $3 \%$ were low risk. Eighty percent of SBPS stands were very high risk. Free-growing densities were likely lower in our surveys than those of the Forest Practices Board (2003) because we focused only on lodgepole pine stands, which may suffer more damage than other species, and because our examinations involved careful and thorough examination of all trees in the plots at the field level. Moreover, the Board focused on plantations that had been recently declared free-growing whereas our sample comprised plantations where the free-growing declaration occurred 5 to 13 years before our survey. Nevertheless, the poor performance that we uncovered is clear evidence that interior lodgepole pine stands are not necessarily going to sustain declared free-growing status, and that timber supply projections are likely to exceed actual yield.

\section{Factors causing free-growing reductions}

The most common cause of damage was stem disease, particularly western gall rust, which occurred on $100 \%$ of our sites and affected one-quarter of stems. The large number of trees rejected as free-growing at the time of our surveys may reflect the fact that rust incidence peaks later than when the original free-growing surveys were done (van der Kamp and Spence 1987, Bella and Navratil 1988, Blenis and Duncan 1997). We found, in general, that lodgepole pine stands were less likely to be free-growing and more likely to be damaged as they aged. Other prevalent damaging agents in our study, such as mountain pine beetle, lodgepole terminal weevil, and red squirrels also favour older (larger) trees (Safranyik et al. 1998, Ransome et al. 2004). In addition, we carefully inspected every side of all trees in our plots, so it is probable that we would see more damage than in typical free-growing surveys where close scrutiny of every tree is unlikely.

Although damage is common in juvenile lodgepole pine stands, the level we observed (55\% overall damage incidence) is generally higher than that reported in the literature. Humphreys and van Sickle (1992) found that 43\%, 16\%, and $3 \%$ of pine were damaged by pests (all severity classes combined) in the central, eastern and northern regions of southern interior British Columbia. They found that stem and branch diseases, including western gall rust, blister rusts and 
Table 5. Percentage of total density of secondary species (i.e., excluding lodgepole pine) damaged by damage category and biogeoclimatic (BEC) zone. See Table 4 for individual damaging agents in each damage category.

\begin{tabular}{lcccccccc}
\hline BEC zone & All agents & All diseases & $\begin{array}{c}\text { Stem } \\
\text { diseases }\end{array}$ & $\begin{array}{c}\text { Foliar } \\
\text { diseases }\end{array}$ & Root diseases & All insects & All animals & All abiotic \\
\hline ESSF & 12.8 & 2.0 & 0.3 & 1.7 & 0 & 2.3 & 2.2 \\
ICH & 23.8 & 8.9 & 2.2 & 4.8 & 1.9 & 1.6 & 2.0 \\
IDF & 12.0 & 0 & 0 & 0 & 0 & 3.7 & 2.8 \\
MS & 24.6 & 5.9 & 0 & 4.8 & 0 & 10.6 & 1.0 \\
SBPS & 19.3 & 3.2 & 2.4 & 0.8 & 0 & 10.5 & 2.4 \\
SBS & 25.7 & 3.2 & 0.7 & 1.3 & 1.1 & 13.4 & 5.5 & 2.3 \\
\hline
\end{tabular}

Table 6. Regression models predicting the logit of the probability of meeting well spaced or free-growing standards or being rejected as free-growing $[p(Y)=e($ logit $) /[1+e($ logit $)]]$ with factors presented in the order they were selected by the stepwise procedure, area under the curve (AUC) ${ }^{\mathrm{a}}$

\begin{tabular}{|c|c|c|}
\hline Agent & Model & AUC \\
\hline Well-spaced & $\begin{array}{l}\operatorname{logit} \mathrm{p}(\mathrm{Y})=3.075-0.275 \text { (soil moisture regime) }-0.006 \text { (summer precipitation) }+1.222 \text { (spacing) } \\
-1.160 \text { (pruning) }\end{array}$ & 0.684 \\
\hline Free-growing & $\begin{array}{l}\operatorname{logit} \mathrm{p}(\mathrm{Y})=2.374+0.001 \text { (elevation) }+0.270(\mathrm{MCMT})-0.056 \text { (age) }-0.871 \text { (broadcast burn) } \\
+1.145 \text { (spacing) }-0.674 \text { (brushing) }\end{array}$ & 0.703 \\
\hline $\begin{array}{l}\text { Rejected as } \\
\text { free-growing }\end{array}$ & $\begin{array}{l}\text { logit } \mathrm{p}(\mathrm{Y})=-21.459+0.278 \text { (latitude) }+0.157 \text { (soil moisture regime) }-0.221 \text { (lower slope position) } \\
+0.358 \text { (upper slope position) }-0.150 \text { (northness) }-0.009 \text { (pine density) }+0.219 \text { (continentality) } \\
+0.0290 \text { (tree age) }-0.240 \text { (spacing) }+0.609 \text { (pruning) }\end{array}$ & 0.680 \\
\hline
\end{tabular}

${ }^{a}$ AUC is a measure of model ability to discriminate between acceptable and unacceptable plots or stems. The degree to which AUC exceeds 0.5 (and approaches 1 ) is a measure of model improvement over random chance.

atropellis cankers, occurred in $49 \%$ of pine stands and infected fewer than $5 \%$ of the trees, rates that are substantially lower than in our study (we found that stem diseases were present on $100 \%$ of sites and affected $24 \%$ of pine). Western gall rust, the most common damaging agent in our stands, has been widely reported to cause severe damage to lodgepole pine (Powell and Hiratsuka 1973, Bella 1985, van der Kamp and Spence 1987). Levels of mammal damage and foliar diseases that we observed, however, were similar to other studies (Humphreys and van Sickle 1992).We found greater incidence of lodgepole pine terminal weevil than Humphreys and van Sickle (1992) but similar amounts as Maclauchlan and Borden (1996). By contrast, we found less Warren's root collar weevil and Armillaria root disease than did Humphreys and van Sickle (1992).

Ours is not the first study to report extensive damage from western gall rust. Wu et al. (2005) found a positive correlation between the presence of this agent and increasingly moist climate, while Heineman et al. (2010) found evidence of increasing risk from this agent under warming climatic conditions. In west-central Alberta, $43 \%$ of lodgepole pine had stem galls from western gall rust at age 26 to 32 and $42 \%$ of stands had stem galls on at least half of the pine (Blenis and Duncan 1997). Other studies from British Columbia and Alberta agree that western gall rust is the most important disease in young, thinned lodgepole pine stands (Bella and Navratil 1988, Woods et al. 2000). Hard pine stem rusts can have considerable impact on timber supply in lodgepole pinedominated areas (Woods et al. 2000). An estimated 15\% of lodgepole pine volume was lost to western gall rust over 20 years in west-central Alberta (Bella and Navratil 1988). Woods et al. (2000) estimated a 7\% mean volume loss at culmination age (age at which the merchantable mean annual increment is maximized) due to western gall rust and comandra rust in central BC. In a stand of 45- to 65-year-old lodgepole pine in interior $\mathrm{BC}$, atropellis canker and stalactiform blister rust reduced the volume of infected trees by $8 \%$ and $6 \%$, respectively, and the potential lumber value of the trees was reduced by $33 \%$ and $29 \%$, respectively (Nevill et al. 1989). The widespread high levels of damage from hard pine stem rusts uncovered in our study suggests that future volume losses from young lodgepole stands in interior British Columbia may be even greater than estimated in earlier studies.

\section{Influence of climatic, environmental and silviculture treatment factors}

The large geographic scale of this study allowed us to identify broad relationships between stocking status and a diverse set of explanatory variables. The three models (predicting freegrowing, well-spaced or rejection as free-growing) were consistently good at discriminating between acceptable and unacceptable plots or stems (AUC 0.684 to 0.703 ). The model predicting well-spaced stocking was slightly poorer than those predicting free-growing (acceptance of plots or rejec- 
Table 7. Lower (LCL) and upper (UCL) odds-ratio confidence limits and probability $>\chi 2$ for the mean for factors predicting the risk of a tree being free-growing, well-spaced or being rejected as free-growing. P-values shown in italics

\begin{tabular}{|c|c|c|c|c|c|c|c|c|c|c|c|}
\hline \multirow{2}{*}{$\begin{array}{l}\text { Factor } \\
\text { type }\end{array}$} & \multirow[b]{2}{*}{ Factor } & \multirow[b]{2}{*}{ Units } & \multicolumn{3}{|c|}{ Free-growing } & \multicolumn{3}{|c|}{ Well-spaced } & \multicolumn{3}{|c|}{ Rejected as free-growing } \\
\hline & & & LCL & UCL & $\operatorname{Pr}>\chi^{2}$ & LCL & UCL & $\operatorname{Pr}>\chi^{2}$ & LCL & UCL & $\operatorname{Pr}>\chi^{2}$ \\
\hline \multirow{3}{*}{ Location } & Elevation & $1 \mathrm{~m}$ & 1.000 & 1.002 & 00282 & - & - & - & - & - & - \\
\hline & Latitude & 1 degree & - & - & - & - & - & - & 1.245 & 1.402 & $<0.0001$ \\
\hline & Longitude & 1 degree & - & - & - & - & - & - & - & - & - \\
\hline \multirow[t]{6}{*}{ Site } & Soil moisture regim & ne 1 unit & - & - & - & 0.642 & 0.900 & 0.0015 & 1.084 & 1.264 & $<0.0001$ \\
\hline & Slope & $1 \%$ & - & - & - & - & - & - & - & - & - \\
\hline & Slope position ${ }^{\mathrm{a}}$ & LW vs. MD & - & - & - & - & - & - & 0.565 & 1.136 & 0.0008 \\
\hline & Slope position ${ }^{\mathrm{a}}$ & UP vs. MD & - & - & - & - & - & - & 1.178 & 1.774 & 0.0004 \\
\hline & Northness & 1 unit & - & - & - & - & - & - & 0.787 & 0.941 & 0.0010 \\
\hline & Eastness & 1 unit & - & - & - & - & - & - & - & - & - \\
\hline \multirow[t]{2}{*}{ Stand } & Stand age & 1 year & 0.902 & 0.991 & 0.0191 & - & - & - & 1.012 & 1.048 & 0.0012 \\
\hline & Pine density & 200 stems/ha & - & - & - & - & - & - & 1.006 & 1.011 & $<0.0001$ \\
\hline \multirow[t]{5}{*}{ Treatment } & Broadcast burn ${ }^{\mathrm{b}}$ & Y vs. $\mathrm{N}$ & 0.275 & 0.637 & $<0.0001$ & - & - & - & - & - & - \\
\hline & Mechanical prep ${ }^{\mathrm{b}}$ & Y vs. N & - & - & - & - & - & - & - & - & - \\
\hline & Spacing $^{\mathrm{b}}$ & Y vs. N & 1.384 & 7.137 & 0.0062 & 1.537 & 7.506 & 0.0025 & 0.627 & 0.987 & 0.0384 \\
\hline & Brushing ${ }^{b}$ & Y vs. N & 0.280 & 0.926 & 0.0271 & - & - & - & - & - & - \\
\hline & Pruning ${ }^{\mathrm{b}}$ & Y vs. $\mathrm{N}$ & - & - & - & 0.136 & 0.720 & 0.0062 & 1.321 & 2.561 & 0.0003 \\
\hline \multirow[t]{9}{*}{ Climatic $^{c}$} & MWMT & $1^{\circ} \mathrm{C}$ & - & - & - & - & - & - & - & - & - \\
\hline & MCMT & $1^{\circ} \mathrm{C}$ & 1.126 & 1.523 & 0.0005 & - & - & - & - & - & - \\
\hline & TD & $1^{\circ} \mathrm{C}$ & - & - & - & - & - & - & 1.170 & 1.324 & $<0.0001$ \\
\hline & MSP & $1 \mathrm{~mm}$ & - & - & - & 0.991 & 0.997 & $<0.0001$ & - & - & - \\
\hline & AH:M & 1 unit & - & - & - & - & - & - & - & - & - \\
\hline & SH:M & 1 unit & - & - & - & - & - & - & - & - & - \\
\hline & $\mathrm{DD}<0$ & 1 degree-day & - & - & - & - & - & - & - & - & - \\
\hline & $\mathrm{DD}>5$ & 1 degree-day & - & - & - & - & - & - & - & - & - \\
\hline & eFFP & 1 Julian day & - & - & - & - & - & - & - & - & - \\
\hline
\end{tabular}

aFor slope position, midslope (MD) is the reference class that other slope positions are compared with. LW refers to lower slope position and UP to upper slope position.

${ }^{b}$ For silviculture treatments, no treatment $(\mathrm{N})$ is the reference class with which the treated class $(\mathrm{Y})$ is compared.

${ }^{\mathrm{c}} \mathrm{MWMT}=$ Mean warmest monthly temperature; MCMT = Mean coldest monthly temperature; $\mathrm{TD}=\mathrm{Continentality}(\mathrm{MWMT}$ minus MCMT); MSP = Mean summer precipitation; AH:M = Annual heat:moisture index (MAT+10)/(MAP/1000); SH:M = Summer heat:moisture index $(\mathrm{MWMT}) /(\mathrm{MSP} / 1000)$; DD $<0=\mathrm{Cooling}$ degree-days $($ degree-days below $0^{\circ} \mathrm{C}$ ); $\mathrm{DD}>5=$ Growing degree-days (degree-days above $5^{\circ} \mathrm{C}$ ); eFFP = Julian date marking end of frost-free period.

tion of trees), probably because well-spaced criteria are less restrictive and easily met across a broad range of environmental conditions. Location and site factors, such as latitude, soil moisture content, slope position and aspect, generally contributed most strongly to all three models. Latitude and continentality were particularly important in predicting whether lodgepole pine stems were rejected as free-growing, probably because of the dominance of lodgepole pine in more northerly ecosystems (e.g., SBS and SBPS zones) than the temperate (IDF and ICH zones) and subalpine ecosystems (ESSF zone) and the prevalence of several pine-specific diseases and insects in the north (Heineman et al. 2010). Although not tested, poor matching of planted lodgepole pine genotypes to latitude likely increased the risk of damage by pathogens and insects, particularly at locations where lodgepole pine is poorly represented in natural stands. The odds that stands were well-spaced decreased and the likelihood that they were damaged increased with increasing soil moisture and summer precipitation, which may result from greater amounts and success of infectious fungal spores under wetter conditions (Safranyik et al. 1998). As well, wetter sites have more abundant competing shrubs and deciduous trees than drier sites in southern interior British Columbia (Simard et al. 2005), which may result in increased host stress and susceptibility to some types of damage (Manion 1991). The seemingly contradictory results in the analysis of slope position and northness, where there was lower probability of individual trees being rejected as free-growing with northness and lower slope positions, may simply reflect the better growing conditions for individual trees in these locations. Climate change models predict that winter precipitation in the ICH zone will increase by 2025 while the climate of current SBS zone will shift to a wetter climate resembling the current ICH zone (Hamann and Wang 2006), which could increase the extent of damage caused by foliar and stem diseases in south and central British Columbia. Maintaining or even enhancing genetic diversity, particularly of rare alleles, in planting stock and silviculture practices will be particularly important in bolstering forest ecosystem resilience to rapidly evolving host-pest dynamics with climate change (Schaberg et al. 2008). The significant correlations we found between stocking declines and precipitation are conservative because they 
are based on climatic averages rather than extreme events, which have the potential to cause high damage. The relationships we detected based on mean climatic variables therefore signal potentially important hazards that could be associated with extreme events.

Treatment factors were generally of secondary importance in the regression models, but the odds ratios show that spacing consistently and strongly increased the likelihood of meeting free-growing and well-spaced standards and lowered the likelihood of trees suffering damage. This result is likely a direct consequence of the spacing treatment, which focuses on removing smaller, unhealthier trees. There is some evidence from other studies that there is lower incidence of certain stem diseases in spaced stands. Atropellis canker, for example, is less common in thinned than unmanaged stands (van der Kamp 1994). However, several studies report either neutral or negative effects of spacing or thinning in lodgepole pine stands on mortality rates due to Armillaria root disease (Cruickshank et al. 1997, Blenis 2000), incidence of western gall rust (Bella 1985), stalactiform blister rust (van der Kamp and Spence 1987), Warren's root collar weevil (Cerezke 1994), lodgepole pine terminal weevil (Maclauchlan and Borden 1996), comandra rust (van der Kamp and Spence 1987), or damage from moose or small mammals (Sullivan and Sullivan 1982, Sullivan and Vyse 1987).

The odds ratios also showed that pruning, brushing or broadcast burning decreased the likelihood of meeting freegrowing standards and increased the likelihood of damage. Severely pruned trees have been shown to suffer more bark beetle attacks than un-pruned trees, which has been attributed to increased tree water stress and release of attractive volatiles released from the branch stubs (Gaudie 2000). Reasons why the likelihood of meeting free-growing declined with broadcast burning are not obvious, but red squirrel damage increases in fire-origin stands compared to unburned stands (Brockley and Elmes 1987, Sullivan et al. 1994). Fireorigin stands tend to be denser and are more likely to be spaced, which leaves high slash cover for squirrels (Sullivan et al. 2002). The likelihood that trees were rejected as free-growing increased with pine density, which is obviously related to the minimum spacing requirement (Table 2). However, juvenile stand density also influences host tree vigour and conditions affecting the incidence of a range of insects and diseases (Safranyik et al. 1998).

\section{Conclusions}

Our finding that over one-quarter of lodgepole pine plantations have substandard stocking levels soon after being declared free-growing as a result of insect, disease and abiotic damage is cause for concern because of the potential for broad-scale reductions in forest yield relative to projections. Reforestation policies that identify lodgepole pine as the preferred species and thus encourage its wide-spread planting should be reconsidered for many areas given that risk of forest decline due to damage increases with changing climatic trends, intensive management practices and stand aging. Planting monocultures should be avoided in general, particularly in areas with limited natural regeneration of other species (e.g., SBS and SBPS zones), and planting of lodgepole pine should be greatly scaled back on sites where we found exceptionally high rates of plantation failure and damage (e.g., the ICH zone and the cold, wet variants of the ESSF zone where snow and ice loads are high). Where site or other factors necessitate planting pure lodgepole pine, and natural regeneration of other species is limited, practitioners should consider increasing the planting density to allow for damage losses. Careful attention must be made to match provenance with site and to maintain genetic diversity to help bolster resilience of plantations against escalating insect and disease problems projected with climate change. While some silviculture treatments should be avoided (e.g., brushing or pruning), spacing treatments could be used to reduce lethal damage to lodgepole pine while favouring secondary species that are ecologically suited to the site, especially where levels of damage on lodgepole pine are high. The need for a new emphasis in the approach to monitoring and managing juvenile lodgepole pine stands in interior British Columbia is obvious from this study. Consideration should be given to establishing an effective permanent plot system for monitoring post-freegrowing stands to ensure that performance is maintained beyond the free-growing declaration and track mortality, damage and forest development. Our study shows that freegrowing and stocking status are linked to climatic conditions, and that shifts in precipitation and winter temperatures with climate change could enhance damage and reduce yield of lodgepole pine stands that are already affected by widespread health problems.

\section{Acknowledgements}

This research was funded by the Forest Investment Account of British Columbia. Funding assistance by the agency does not imply endorsement of any statements or information presented here. Valuable advice and support during the initiation of this project was provided by BC Ministry of Forests and Range personnel Wendy Bergerud, Michelle Cleary, Lorraine Maclauchlan, Alex Woods, and Sharon Cadieux. We are also grateful for advice and review comments on an earlier version of the manuscript from Alan Vyse at Thompson Rivers University. We thank David Sword and Maureen Ganton for field support, and we are also grateful to members of the forestry community of British Columbia who provided anecdotal information regarding individual damaging agents that guided development of our field sampling plan.

\section{References}

Allen, C.D. et al. 2010. A global overview of drought and heatinduced tree mortality reveals emerging climate change risks for forests. Forest Ecology and Management 259: 660-684.

Bella, I.E. 1985. Western gall rust and insect leader damage in relation to tree size in young lodgepole pine in Alberta. Canadian Journal of Forest Research 15: 1008-1010.

Bella, I.E. and S. Navratil. 1988. Western gall rust dynamics and impact in young lodgepole pine stands in west-central Alberta. Canadian Journal of Forest Research 18: 1437-1442.

Blenis, P.V. 2000. Post-spacing mortality of lodgepole pine from Armillaria root disease. The Forestry Chronicle 76: 753-757.

Blenis, P.V. and I. Duncan. 1997. Management implications of western gall rust in precommercially thinned lodgepole pine stands. Canadian Journal of Forest Research 27: 603-608.

[BCMF] British Columbia Ministry of Forests. 2000. Establishment to free-growing guidebook: Kamloops Forest Region, Revised edition, British Columbia Ministry of Forests, Forest Practices Branch, Victoria, BC. Forest Practices Code of BC Guidebook, Version 2.2 .

.2002. Stocking and free growing survey procedures manual. BC Ministry of Forests, Forest Practices Branch, Victoria, BC. Avail- 
able at http://www.llbc.leg.bc.ca/public/pubdocs/bcdocs/360736/ surveysprocmanual3.pdf.

[BCMFR] British Columbia Ministry of Forests and Range. 2002-2009. Annual reports. British Columbia Ministry of Forests and Range, Victoria, BC. Available at http://www.for.gov.bc.ca/mof/ annualreports.htm.

Brockley, R.P. and E. Elmes. 1987. Barking damage by red squirrels in juvenile-spaced lodgepole pine stands in south-central British Columbia. The Forestry Chronicle 63: 28-31.

Burns, R.M. and B.H. Honkala. 1990. Silvics of North America, Vol. 1. USDA Forest Service, Agricultural Handbook 654.

Cardinale, B.J., D.S. Srivastava, J.E. Duffy, J.P. Wright, A.L. Downing, M. Sankaran and C. Jouseau. 2006. Effects of biodiversity on the functioning of trophic groups and ecosystems. Nature 443: 989-992.

Chapin III, F.S., J.T. Randerson, A.D. McGuire, J.A. Foley and C.B. Field. 2008. Changing feedbacks in the climate-biosphere system. Frontiers in Ecology and the Environment 6: 313-320.

Claveau, Y., C. Messier, P.G. Comeau and K.D. Coates. 2002. Growth and crown morphological responses of boreal conifer seedlings and saplings with contrasting shade tolerance to a gradient of light and height. Canadian Journal of Forest Research 32: $458-468$

Cruickshank, M.G., D.J. Morrison and Z.K. Punja. 1997. Incidence of Armillaria species in precommercial thinning stumps and spread of Armillaria ostoyae to adjacent Douglas-fir trees. Canadian Journal of Forest Research 27: 481-490.

Cerezke, H.F. 1994. Warren root collar weevil, Hylobius warreni Wood (Coleoptera, Curculionidae) in Canada: ecology, behaviour, damage relationships, and management. Canadian Entomologist 126: $1383-1442$.

Folke, C., S. Carpenter, B. Walker, M. Scheffer, T. Elmqvist, L. Gunderson and C.S. Holling. 2004. Regime shifts, resilience, and biodiversity in ecosystem management. Annual Review of Ecology, Evolution, and Systematics 35: 557-581.

Forest Practices Board. 2003. Reforesting BC's public land - An evaluation of free-growing success. Special Report No. 16.

Gaudie, J.E. 2000. The implications of thinning and pruning on the incidence of pests in a lodgepole pine plantation in the interior of British Columbia. M.Sc. Thesis. Dept. of Biological Sciences, Simon Fraser University, Burnaby, BC.

Hamann, A. and T. Wang. 2006. Potential effects of climate change on ecosystem and tree species distribution in British Columbia. Ecology 87: 2773-2786.

Heineman, J.L., D.L. Sachs, W.J. Mather and S.W. Simard. 2010. Investigating the influence of climatic, site, location, and treatment factors on damage to young lodgepole pine in southern British Columbia. Canadian Journal of Forest Research 40: 1109-1127.

Henigman, J., T. Ebata, E. Allen, J. Westfall and A. Pollard. 2001. Field guide to forest damage in British Columbia. Forestry Canada and BC Ministry of Forests, Victoria, BC. Joint Publication 17.

Humphreys, N. and van Sickle, G.A. 1992. Surveys of forest health in young stands in British Columbia. Canadian Forestry Service and British Columbia Ministry of Forests. FRDA Report 190.

Kelty, M.J. 2006. The role of species mixtures in plantation forestry. Forest Ecology and Management 233: 195-204.

Klinka K, J. Worrall, L. Skoda and P. Varga. 2000. The distribution and synopsis of ecological and silvical characteristics of tree species of British Columbia's forests. Canadian Cartographics Ltd., Burnaby, BC. 180 p.

Kobe, R.K. and K.D. Coates. 1997. Models of sapling mortality as a function of growth to characterize interspecific variation in shade tolerance of eight tree species of northwestern British Columbia. Canadian Journal of Forest Research 27: 227-236.

Kurz, W.A., C.C. Dymond, G. Stinson, G.J. Rampley, E.T. Neilson, A.L. Carroll, T. Ebata and L. Safranyik. 2008. Mountain pine beetle and forest carbon feedback to climate change. Nature 452: 987-990.
Lieffers, V.J., K.J. Stadt and Z. Feng, Z. 2007. Free-to-grow regeneration standards are poorly linked to growth of spruce in boreal mixedwoods. The Forestry Chronicle 83: 818-824.

Lloyd, D., K. Angove, G. Hope and C. Thompson. 1990. A guide to site identification and interpretation for the Kamloops Forest Region. Land Management Handbook No. 23. British Columbia Ministry, 'Forests, Victoria, BC.

Lorimer, G. 1981. Survival and growth understory trees in oak forests of uie Hudson Highlands, New Y.k. Canadian Journal of Forest Research 11: 689-695.

Maclauchlan, L.E. and J.H. Borden. 1996. Spatial dynamics and impacts of Pissodes terminalis (Coleoptera: Curculionidae) in regenerating stands of lodgepole pine. Forest Ecology and Management 82: 103-113.

Manion, P.D. 1991. Tree Disease Concepts. $2^{\text {nd }}$ Ed. Prentice-Hall, Engelwood Cliffs, N.J. 402 p.

Meidinger, D. and Pojar, J. 1991. Ecosystems of British Columbia. British Columbia Ministry of Forests, Victoria, BC

MacKenzie, W. and D. Meidinger. 2006. The ecology of the Alpine zones. Brochure 83. British Columbia Ministry of Forests and Range, Victoria, BC.

Mitchell, K.J. 1975. Dynamics and simulated yield of Douglas-fir. Forest Science Monograph 17.

Mitchell, K.J., S.E. Grout, R.N. McDonald and C.A. Watmough. 1992. User's Guide for TIPSY: A Table Interpolation for Stand Yields. BC Ministry of Forests, Victoria, BC.

Nevill, R.J., J.H. Borden and H. Merler. 1989. Reduced volume, grade, and value of lodgepole pine lumber caused by Atropellis canker and stalactiform blister rust. The Forestry Chronicle 65: 36-41.

Perry, D.A., R. Oren and S.C. Hart. 2008. Forest Ecosystems. $2^{\text {nd }}$ Edition. The Johns Hopkins University Press, Baltimore. 606 p.

Powell, J.M. and Y. Hiratsuka. 1973. Serious damage caused by stalactiform blister rust and western gall rust to a lodgepole pine plantation in central Alberta. Canadian Plant Diseases Survey 53: 67-71. Ransome, D.B., P.M.F. Lindgren, D.S. Sullivan and T.P. Sullivan. 2004. Long-term responses of ecosystem components to stand thinning in young lodgepole pine forest: I. Population dynamics of northern flying squirrels and red squirrels. Forest Ecology and Management 202: 355-367.

Robert, J.A. and B.S. Lindgren. 2006. Relationships between root form and growth, stability, and mortality in planted versus naturally regenerated lodgepole pine in north-central British Columbia. Canadian Journal of Forest Research 36: 2642-2653.

Safranyik, L., R. Nevill and D. Morrison. 1998. Effects of stand density management on forest insects and diseases. Technical Transfer Note No. 12. Canadian Forestry Service, Victoria, BC.

SAS Institute, Inc. 2002-2003. SAS 9.1.3. Cary, NC.

Schaberg, P.G., D.H. DeHayes, G.J. Hawley and S.E. Nijensohn. 2008. Anthropogenic alterations of genetic diversity within tree populations: Implications for forest ecosystem resilience. Forest Ecology and Management 256: 855-862.

Scherer-Lorenzen, M, C. Körner and E.-D. Schulze. 2005. Forest Diversity and Function: Temperate and Boreal Systems. SpringerVerlag, Heidelberg. Ecological Studies 157. 400 p.

Simard, S.W., S.M. Hagerman, D.L. Sachs, J.L. Heineman and W.J. Mather. 2005. Conifer growth, Armillaria ostoyae root disease and plant diversity responses to broadleaf competition reduction in temperate mixed forests of southern interior British Columbia. Canadian Journal of Forest Research 35: 843-859.

Simard, S.W. and A. Vyse. 2006. Trade-offs between competition and facilitation: A case study of vegetation management in the interior cedar-hemlock forests of southern British Columbia. Canadian Journal of Forest Research 36: 2486-2496.

Sullivan, T.P., J.A. Krebs and P.K. Diggle. 1994. Prediction of stand susceptibility to feeding damage by red squirrels in young lodgepole pine. Canadian Journal of Forest Research 24: 14-20. 
Sullivan, T.P. and D.S. Sullivan. 1982. Barking damage by snowshoe hares and red squirrels in lodgepole pine stands in central British Columbia. Canadian Journal of Forest Research 12: 443-448. Sullivan, T.P., D.S. Sullivan, P.M.F. Lindgren, P.M.F. and J.O. Boateng. 2002. Influence of conventional and chemical thinning on stand structure and diversity of plant and mammal communities in young lodgepole pine forest. Forest Ecology and Management 170: 173-187.

Sullivan, T.P. and A. Vyse. 1987. Impact of red squirrel feeding damage on spaced stands of lodgepole pine in the Cariboo Region of British Columbia. Canadian Journal of Forest Research 17: 666-674. Tilman, D., J. Knops, D. Wedin, P. Reich, M. Ritchie and E. Siemann. 1997. The influence of functional diversity and composition on ecosystem processes. Science 277: 1300-1302.

van der Kamp, B.J. 1994. Lodgepole pine stem diseases and management of stem density in the British Columbia interior. The Forestry Chronicle 70: 773-779.

van der Kamp, B. and M. Spence. 1987. Stem diseases of lodgepole pine in the British Columbia interior following juvenile spacing. The Forestry Chronicle 63: 334-339.
Vyse, A., C. Ferguson, D.J. Huggard, J. Roach and B. Zimonick. 2009. Regeneration beneath lodgepole pine dominated stands attacked or threatened by the mountain pine beetle in the south central Interior, British Columbia. Forest Ecology and Management 258: S36-S43.

Wang, T., A. Hamann, D.L. Spittlehouse and S.N. Aitken. 2006. Development of scale-free climate data for western Canada for use in resource management. International Journal of Climatology 26: 383-397.

Woods, A., K.D. Coates and A. Hamann. 2005. Is an unprecedented Dothistroma needle blight epidemic related to climate change? BioScience 55: 761-769.

Woods, A.J., A. Nussbaum and B. Golding. 2000. Predicted impacts of hard pine stem rusts on lodgepole pine dominated stands in central British Columbia. Canadian Journal of Forestry Research 30: 476-481.

Wu, H.X, C.C. Ying and H.B. Ju. 2005. Predicting site productivity and pest hazard in lodgepole pine using biogeoclimatic system and geographic variables in British Columbia. Annals of Forest Science 62: $31-42$. 